\title{
ЗАКОНОДАТЕЛЬНОЕ РЕГУЛИРОВАНИЕ ОРГАНИЗАЦИИ ТАМОЖЕННОЙ ДЕЯТЕЛЬНОСТИ НА ГРАНИЦЕ СОПРЕДЕЛЬНЫХ ГОСУДАРСТВ РОССИИ И УКРАИНЫ В ПОСТСОВЕТСКИЙ ПЕРИОД
}

\author{
(C) 2021 Абашева Екатерина Александровна \\ кандидат юридических наук, доцент кафедры социальных технологий и государственной службы \\ Института экономики и управления \\ БелГУ, Россия, Белгород \\ E-mail: abasheva229@mail.ru
}

(c) 2021 Колесникова Елена Валентиновна

ассистент кафедры социальных технологий и государственной службы

Института экономики и управления

БелГУ, Россия, Белгород

E-mail: elena.kolesnickowa@yandex.ru

Политические, экономические и социальные отношения суверенных государств России и Украины имеют многовековую историю. Сложившиеся в последние годы благодаря вмешательству прозападных сил российско-украинские отношения приобрели геополитический характер. Выстраиваемые десятилетиями внешнеэкономические связи между пограничными государствами, исследуемыми в данной статье, привели к практически полному разрыву экономических отношений между некогда дружественными странами. Авторы статьи рассматривают формирование российско-украинского приграничья на законодательном уровне в первые годы после распада Советского Союза.

Ключевые слова: государственная граница, территория государства, пограничный режим, таможенная служба, погранично-таможенный контроль.

Таможенная служба, призванная обеспечивать экономическую безопасность государства, выступает одним из важнейших государственных институтов. Установление таможеных границ между сопредельными государствами в первую очередь предполагает закрепление на законодательном уровне установление государственных границ с обязательным пограничным контролем государственных территорий.

Нормативно-правовая регламентация сопредельных государств России и Украины на государственном уровне призвана регулировать стабильность отношений и безопасность государственных границ приграничных территорий, которые в силу распада некогда единого огромного государства СССР, занимающего в свое время шестую часть суши нашей планеты, оказались по разные стороны территориальных границ. Слом политического единства Советского Союза, привел к прекращению не только политического единства бывших республик, входящих в его состав, но и к разрыву экономических, культурных и социальных отношений между народами, бывшими когда-то частью Великой державы. Российско-украинские отношения на сегодняшний день, во многом благодаря враждебно настроенной по отношению к России политики украинских властей, представляют собой одну из драматических страниц современной реальности.

Федеральное агентство по устройству государственной границы Российской Федерации определяет, что протяженность российско-украинской границы (сухопутной, морской - проходящими по акватории Черного и Азовского морей, речной и озерной) и после включения в состав России республики Крым и города Севастополя (благодаря которому сухопутная граница, проходящая по Перекопскому перешейку, увеличила протяженность границы на 8 км), составляет около 2258 км [15].

Российская Федерация, будучи по международному праву правопреемницей СССР, в том числе и в отношении государственной границы, граничит с Украинским государством со стороны России по территории шести субъектов - Pe- 
спубликой Крым, Белгородской, Брянской, Воронежской, Курской и Ростовской областей, со стороны же Украины по отношению к России приграничными регионами являются Донецкая, Луганская, Сумская, Харьковская, Херсонская и Черниговская области.

Важно отметить, что еще до начала вмешательства в российско-украинские отношения прозападных сил и как следствие - украинских событий в 2014 году (отстранение от власти Президента страны В.Януковича, вследствие военного переворота), приведших к разрыву установленных ранее добрососедских отношений приграничных государств, 31.05.1997 года между Москвой и Киевом был заключен Договор о дружбе, сотрудничестве и партнерстве между Российской Федерацией и Украиной (по условиям закрепленным в договоре - он должен был продлеваться автоматически каждые 10 лет) [4], по которому оба государства признавали отсутствие взаимных территориальных претензий, территориальную целостность и государственные границы, в основе своей предполагающий стратегическое партнерство обеих стран. Договор в одностороннем порядке (по решению Верховной Рады - парламента Украины) в декабре 2018 года был расторгнут, что по сути закрепило с 01.04.2019 года прекращение действия условий Договора [12].

События 16.07.1990 года (дата принятия Декларации о государственном суверенитете Украины) [3], 04.11.1991 года - дата принятия парламентом украинского государства Законов «О государственной границе Украины» [6] и Закона «О пограничных войсках Украины» [11] и 24.08.1991 года (дата объявления Украиной независимости от Советского Союза) [1], означавшие установление государственной границы между российским и украинским государствами, привели к заключению в Дагомысе 23.06.1992 года Соглашения между Россией и Украиной о дальнейшем развитии межгосударственных отношений [18], предусматривавшем сохранение принципа открытости границ при поэтапном введении таможенного контроля, соответствующего международным стандартам.

Установление самих таможенных границ и пунктов таможенного досмотра и контроля в рамках правового поля между странами связано с принятием Указа Президента РФ «О неотложных мерах по организации таможенного контроля в Российской Федерации» от 18.07.1992 года
[9], во исполнение которого Правительством России от 25.08.1992 года было принято соответствующее Постановление № 624 [8] и Распоряжением Президента Украины от 12.10.1992 года «О пограничном таможенном контроле на государственной границе с Республикой Беларусь и Российской Федерацией» [11].

Опыт в сфере организации охраны границ обоих приграничных государств, желающих закрепить свой суверенитет на государственную границу, нашел отражение на законодательном уровне в Законах Украины 04.11.1991 года «О Государственной границе Украины» [6] и России от 01.04.1993 года «О Государственной границе Российской Федерации» [5]. Законодательные акты в своем содержании определяли полномочия субъектов охраны границ и пограничных войск, ответственность за правонарушения при незаконном пересечении государственной границы и конечно же нормы, регулирующие режимные мероприятия на государственной границе обеих стран (принципы прохождения и изменения государственных границ, ее защиты и охраны; обозначение и установление режима; режим въезда (выезда) и пересечение лицами и транспортными средствами; ведение хозяйственной и промысловой деятельности на границе; полномочия органов государственной власти, вооруженных сил (воинских формирований) и органов МСУ, предприятий, учреждений, организаций и общественных объединений, участвующих в защите государственных границ).

В связи с новым историческим этапом развития таможенной службы России Указом Президента РСФСР Б.Н.Ельциным 25.10.1991 года был учрежден Государственный таможенный комитет РСФСР [7], во исполнение данного правового акта, Правительство РСФСР 26.12.1991 г. приняло Постановление «Вопросы Государственного таможенного комитета РСФСР» [2]. Впоследствии 09.03.2004 года Государственный таможенный комитет по Указу Президента РФ В.В.Путина, касающегося системы и структуры федеральных органов исполнительной власти российского государства, был преобразован в Федеральную таможенную службу России [13], действующую по настоящее время и являющуюся правопреемником всех таможенных структур российского государства.

Регулирование таможенной деятельности на законодательном уровне в освещаемый период было закреплено в ходе принятия 21.05.1993 
года Закона РФ о Таможенном тарифе [14] и 18.06.1993 года Таможенного кодекса РФ [20].

Со стороны российского государства таможенный контроль в пограничных пунктах пропуска на российско-украинской границе был установлен 15 февраля 1993 года (изначально это было 35 подразделений, включая 22 автодорожных и 13 железнодорожных пунктов пропуска) [17]. Государственная пограничная служба Украины со стороны украинского государства определила следующие международные автомобильные и железнодорожные пункты пропуска: в Харьковской области - 8; в Сумской области 8 ; в Черниговской области - 2; станция «Киев Пассажирский» [16].

Совместное патрулирование границ пограничными войсками России и Украины началось с момента подписания в Одессе 03.08.1994 года Соглашения между Российской Федерацией и Украиной о сотрудничестве и взаимодействии по пограничным вопросам [19], из текста которого на тот период времени прослеживается четкая и явная заинтересованность приграничных государств в осуществлении эффективного сотрудничества в решении практических во- просов охраны своих государственных границ, а также курс на дальнейшее развитие добрососедских отношений « ... укрепление отношений дружбы, добрососедства и сотрудничества между Сторонами отвечают коренным национальным интересам их народов и служат делу мира и безопасности» [19]. Пограничный контроль устанавливался только при въезде в сопредельные государства.

Вышеупомянутая цитата из Соглашения, четко демонстрирует отказ Украины следовать букве закона, заключенного ранее украинскими же властями. Сопредельное с российским государством - Украина, охваченная конфликтами, где в самом государстве уже нарушена политическая и экономическая стабильность, сегодня придерживается прозападных фронтиров, которые выражаются не только в негативно направленных в сторону России настроениях политической элиты страны, но и в не скрываемой готовности перейти к открытым военным конфликтам. Все это, безусловно, накладывает особый отпечаток на российско-украинские отношения.

\section{Библиографический список}

1. Акт провозглашения независимости Украины от 24.08.1991 г.: Постановление Верховного Совета Украинской ССР // Ведомости Верховной Рады. 1991. № 38. Ст. 502.

2. Вопросы Государственного таможенного комитета РСФСР: Постановление Правительства РСФСР от 26.12.1991 г. № 65 (утратил силу 27.08.1999) / КонсультантПлюс. URL: http://www.consultant.ru/document/ cons_doc_LAW_2139/(дата обращения: 25.07.2021)

3. Декларация о государственном суверенитете Украины от 16.07.1990 г. // Ведомости Верховной Рады УРСР. 1990. № 31. Ст.429.

4. Договор о дружбе, сотрудничестве и партнерстве между Российской Федерацией и Украиной от 31.05 .1997 г. (утратил силу 01.04.2019) / Электронный фонд правовых и нормативно-технических документов. URL: http://pravo.gov.ru/ (дата обращения: 25.07.2021)

5. О Государственной границе Российской Федерации: Закон РФ от 01.04.1993 г. № 4730-I (ред. от 11.06.2021) / Гарант. URL: https://base.garant.ru/10103372/ (дата обращения: 25.07.2021)

6. О Государственной границе Украины: Закон от 04.11.1991 г. № 1777-XII (ред. от 03.12.2020) / Инфрмационная система «Контитент». URL: http://search.ligazakon.ua/__doc2.nsf/link1/T177700.html (дата обращения: 25.07.2021)

7. О Государственном таможенном комитете РСФСР: Указ Президента РСФСР от 25.10.1991 г. № 161 / Ельцин Центр. URL: https:/yeltsin.ru/archive/act/33702/ (дата обращения: 25.07.2021)

8. О мерах по реализации Указа Президента РФ от 18.07.1992 г. № 788 «О неотложных мерах по организации таможенного контроля в Российской Федерации»: Постановление Правительства РФ от 25.08.1992 г. № 624 (утратило силу 29.10.2012) / Гарант. URL: https://base.garant.ru/10104427/ (дата обращения: 25.07.2021)

9. О неотложных мерах по организации таможенного контроля в Российской Федерации: Указ Президента РФ от 18.07.1992 г. № 788 (утратил силу 30.09.2012) / Гарант. URL: https://base.garant.ru/10105695/ (дата обращения: 25.07.2021)

10. О пограничном таможенном контроле на государственной границе с Республикой Беларусь и Российской Федерацией: Распоряжение Президента Украины от 12.10.1992 года № 160/92-рп / Главный правовой партал Украины «Лига: Закон». URL: http://search.ligazakon.ua/l (дата обращения: 25.07.2021) 
11. О пограничных войсках Украины: Закон от 04.11.1991 г. № 1779-XII (утратил силу) / Главный правовой портал Украины «Лига: Закон». URL: http://search.ligazakon.ua/__doc2.nsf/link1/T177900.html (дата обращения: 25.07.2021)

12. О прекращении действия Договора о дружбе, сотрудничестве и партнерстве между Российской Федерацией и Украиной, подписанного в Киеве 31.05 .1997 г.: Официальное сообщение Министерства иностранных дел РФ от 01.04.2019 г. / Электронный фонд правовых и нормативно-технических документов. URL: https:// docs.cntd.ru/document/542644574 (дата обращения: 25.07.2021)

13. О системе и структуре федеральных органов исполнительной власти: Указ Президента РФ от 09.03 .2004 № 314 (ред. от 20.11.2020) / КонсультантПлюс.URL: http://www.consultant.ru/document/cons_doc_LAW_46892/ (дата обращения: 25.07.2021)

14. О таможенном тарифе: Закон РФ от 21.05.1993 № 5003-1 (ред.22.12.2020) / КонсультантПлюс. URL: http:// www.consultant.ru/document/cons_doc_LAW_1995/(дата обращения: 25.07.2021)

15. О Федеральном агентстве по обустройству государственной границы РФ: Постановление Правительства РФ от 01.11.2007 г. № 734 (утратило силу в связи с упразднением и передачей функций Министерству транспорта РФ) / Гарант. URL: https://base.garant.ru/192157/ (дата обращения: 25.07.2021)

16. Пункты пропуска из России в Украину таможенные и пограничные переходы / Информационноюридическая поддержка социальных проблем «Россия-Украина» URL: https://russia-ukraine.com/punktypropuska-iz-rossii-v-ukrainu-tamozhennye-i-2/ (дата обращения: 25.07.2021)

17. Российско-украинская граница. Досье / Тасс. URL: https://tass.ru/info/1267817 (дата обращения: 25.07.2021)

18. Соглашение между Российской Федерацией и Украиной о дальнейшем развитии межгосударственных отношений от 23.06.1992 г. // Ведомости Верховной Рады. 1991. № 38. Ст. 502.

19. Соглашение между Российской Федерацией и Украиной о сотрудничестве и взаимодействии по пограничным вопросам от 03.08.1994 г. / Электронный фонд правовых и нормативно-технических документов. URL: https://docs.cntd.ru/document/902331501 (дата обращения: 25.07.2021)

20. Таможенный кодекс Российской Федерации: Федеральный закон от 18.06.1993 № 5221-1 (утратил силу) / КонсультантПлюс.URL: http://www.consultant.ru/document/cons_doc_LAW_624/(дата обращения: 25.07.2021) 